\title{
A Standard of Fairness for Compensating Preferred Shareholders in Corporate Recapitalizations
}

It is not uncommon for cumulative preferred stock to accumulate large arrears of undeclared and unpaid dividends. Corporations have developed several recapitalization devices to strip preferred shareholders of these arrears without compensation. Most commentators agree that preferred shareholders should be fairly compensated in recapitalizations and that a "clear standard" of full compensation is desirable ${ }^{1}$ for its prophylactic effect upon directors and common stockholders considering the removal of preferred arrears as well as for its ease of judicial or administrative application, yet no commentator has suggested an adequate standard of "fairness." The primary concern of this comment is to suggest an appropriate standard for fully compensating preferred shareholders for the loss of arrears in the recapitalization of a solvent corporation. The availability of a clear and workable standard should dispel judicial hesitancy toward inferring a requirement of fairness into statutes authorizing recapitalizations and should also serve as a guide to those few states which have experimented with such a requirement.

\section{The Propriety of Fairly Compensating the Preferred}

Arrears may accumulate in several ways. For example, management may not declare dividends for some time because of small profits or because cash is needed for expansion or renovation. If, after passing through such a period, the corporation's cash and profits situation improves, management may be eager to resume dividend payments. However, because of the cumulative feature of the preferred stock, the corporation can pay no dividends on common stock until it has satisfied all arrears on the preferred in addition to current preferred dividend requirements. For a variety of reasons-the directors may own common stock, may be controlled closely by common shareholders, or may feel a responsibility to common shareholders and not to the preferredwhen arrears accumulate, management often desires to pay dividends on the common stock immediately. To be able to do so, it must eliminate preferred arrears.

1 See, e.g., Becht, Alterations of Accrued Dividends: I, 49 Mrch. L. REv. 363 (1951). 
This is not difficult to accomplish. ${ }^{2}$ It is commonly said that accruals are not debts, ${ }^{3}$ and whereas a corporation may not modify a debt without the consent of the creditor, ${ }^{4}$ modification of dividend arrears is permissible because it is authorized by statute. The general approach, phrased in terms of traditional contract doctrine, is that arrears may be eliminated if the preferred contract so permits, but not otherwise. ${ }^{5}$ However, even if the contract itself is silent on the issue ${ }^{6}$ most states have statutes which permit the elimination of arrears by charter amendment with the assent of a given percentage, usually two-thirds, of the shareholders affected. "These statutes have been held to be "part" of the preferred "contract."s Although it is easy to understand why common shareholders readily assent to such charter amendments, the motivation of the preferred shareholders is not so clear. ${ }^{9}$ One thing is certain: they

2 See generally Becht, supra note 1; Annot., 8 A.L.R.2d 893 (1949).

318 C.J.S. Corporations $\$$ 235, at 666; Walker, Fairness in State Court Recapitalization Plans-A Disappearing Doctrine, 29 B.U.L. Rev. 453, 456 (1949). But see Ballantine, CoRporations $\S 278 \mathrm{a}$, at 661-62 (1946 ed.): "This is anomalous, as preferred shares are a kind of creditor-shares, first cousins to debts, in their relation to the common shares."

415 Fletcher, Corporations \$ 7302, at 581-82 (1961 ed.). Debts, like shares, may be modified if the contract or a statute so provides. Ibid. But whereas statutes permitting changes in preferred shares exist in nearly all states, no statute permits a majority of creditors or bondholders to bind other creditors to a modification of their claims against a solvent concern. A creditor could only be so bound if his claim arose from a debt contract which expressly provided for majority modification.

519 AM. JUR. 2D Corporations § 885, at 366-67, § 1498, at 880 (1965).

6 One writer has acidly commented that "no lawyer has been forthright enough to draft the preferred stock certificate along the following lines: This stock is prior to all others ... [ [and has various rights unless the majority of preferred shareholders changes its mind] in which case this stock is no better than second preferred and perhaps worse, bears one per cent dividends which are noncumulative, has no liquidation or sinking fund rights, and will lose all dividends that shall have been passed before the majority has made up its mind to terminate your rightsl" Orschel, Administrative Protection for Shareholders in California Recapitalizations, 4 STAN. L. REv. 215 (1952).

In Langenfelder v. Universal Laboratories, Inc., 163 F.2d 804 (3d Cir. 1947), the court said that Delaware law permitted the corporation to eliminate preferred arrears by statutory merger even where the preferred contract (corporate charter) expressly prohibited the elimination of arrears without a specified compensation. See also Jones v. St. Louis Structural Steel Co., 267 Ill. App. 576 (1932).

7 See authorities cited in Annot., 8 A.L.R.2d 893 (1949).

819 AM. JUR. 2D Corporations $\$ 1498$, at 880 (1965). See also Federal United Corp. v. Havender, 24 Del. Ch. 318, 11 A.2d 331 (Sup. Ct. 1940). Some courts distinguish between statutes passed before and those passed after the preferred contract was executed. The former should have been known to the parties when they contracted and are thus deemed to be incorporated into the contract, whereas the latter are not considered part of the preferred contract. See, e.g., Franzblau v. Capital Sec. Co., 2 N.J. Super. 517, 525-26, 64 A.2d 644, 648 (Ch. 1949). Some states permit elimination of dividends accrued after the statute was passed but not those accrued before. See Buxbaum, Preferred Stock-Law and Draftsmanship, 42 CallF. L. Rev. 243, 299-300 (1954).

9 For a discussion of the pressures on preferred shareholders to assent to such plans, 
do assent, ${ }^{10}$ and the legal effect of their doing so is to eliminate dissenters' arrears as well as their own, despite the fact that the preferred often gets very little or nothing in return for making this sacrifice.

An alternative device, more sophisticated in that it is less overt in coercing dissenting preferred shareholders to part with something of value for nothing in return, is euphemistically styled the "voluntary" plan. The plan does not force dissenters to participate; it gives them the option of keeping their shares or exchanging them for prior preferred shares which have no arrears but have a claim to future dividends prior to that of the old preferred. ${ }^{11}$ If earnings are expected to be so small in the near future as to be sufficient only to pay dividends on the prior preferred, the old preferred will convert rather than see the corporation's cash paid out to others while they receive nothing. Very few have the patience to wait out such a tactic and hold their old preferred in the knowledge that their arrears must be satisfied fully before the common can receive anything. ${ }^{12}$

Arrears may also be eliminated by merging the corporation with a subsidiary shell and exchanging preferred in the new corporation, without arrears, for the preferred of the "old" parent corporation, even when the sole purpose of the merger is the elimination of the arrears. ${ }^{13}$ The same result may be achieved by a consolidation or sale of assets. These plans are coercive in that dissenters cannot choose to hold their old securities, but differ from the usual coercive plan in that most states grant a right of appraisal in mergers. ${ }^{14}$ Whatever device is used, it has not been difficult in practice for a corporation to eliminate preferred arrears. ${ }^{15}$

see, e.g., Latty, Exploration of Legislative Remedies for Prejudicial Changes in Senior Shares, 19 U. CHI. L. REv. 759, 764-67 (1952); Note, The Rights of Cumulative Preferred Stockholders Under the Public Utility Holding Company Act, 52 HARv. L. REv. 1331 (1939).

10 See Latty, Fairness-The Focal Point in Preferred Stock Arrearage Elimination, 29 VA. L. REv. 1, 22-23 (1942).

11 Most states, even those which do not permit involuntary arrearage elimination by charter amendment, permit "voluntary" plans. See id. at 7. But see Patterson v. Durham Hosiery Mills, 214 N.C. 806, 812, 200 S.E. 906, 909 (1939): "We do not consider that the alternative offered plaintiffs is a free choice ...."

12 See Note, supra note 9 , at $1336-37$, for a brief discussion of how the "voluntary" plan works.

13 See, e.g., Hottenstein v. New York Ice Mach. Corp., 136 F.2d 944 (3d Cir. 1943) (Del. law); Federal United Corp. v. Havender, 24 Del. Ch. 318, Il A.2d 381 (Sup. Ct. 1940); Anderson v. Cleveland Cliffs Iron Co., 40 Ohio Op. 130, 73 N.E.2d 384 (C.P. 1948).

14 Baker \& Cary, Cases on Corporations 96 (3d ed. 1959). See note 93 and discussion accompanying notes 102-107 infra.

15 For a discussion of the various ways in which accruals can be eliminated, see Becht, supra note 1. 
There has been a loud outcry in the legal literature for nearly three decades demanding that the preferred shareholder be "protected" against the elimination of his accruals. ${ }^{16}$ Whether such protection is warranted depends on the preferred stock contract or, more specifically, on the reasonable expectations of the preferred shareholders with regard to accrued but undeclared dividends.

Apparently it is rare for a preferred stock contract to recite that arrears may be eliminated by a two-thirds vote of the shareholders. Rather, courts say that such a provision is "incorporated" into the contract via statutes which authorize the corporation so to act. ${ }^{17}$ In determining the content of the contract actually made by the parties ${ }^{18}$ respecting dividend cumulations-what they should reasonably expect their respective rights and priorities to be-one could say, as the courts implicitly have, that the statute authorizing accrual elimination is part of the contract, that the preferred shareholders are responsible for knowing this just as if it had been written into the document they signed, and that they are bound by it regardless of what they thought they were contracting for. ${ }^{19}$ But such a construction seems unjust, and would enforce a contract the parties never intended to make. As one commentator put it, "these alterations [of preferred rights by charter amendment] may go further than a shareholder thought possible at the time he purchased his holdings. Included in . . . [his rights]-all of which can be altered by appropriate vote-may be features which he thought to be intrinsic and unalterable elements of his stock."20 Surely the right to receive dividends before any are awarded to the common stock, such dividends to accrue each year and to accumulate when not paid, is just such a feature and was considered by all parties in interest at the time of contracting to be an "intrinsic and unalterable element"

16 See, e.g., ibid.; Dodd, Fair and Equitable Recapitalizations, 55 HARv. L. REv. 780 (1942); Latty, Exploration of Legislative Remedies for Prejudicial Changes in Senior Shares, 19 U. CHI. L. REv. 759 (1952); Note, Protection for Shareholder Interests in Recapitalizations of Publically Held Corporations, 58 Colum. L. REv. 1030 (1958). But see Gibson, How Fixed are Class Shareholder Rights?, 23 LAw \& Contemp. Prob. 283 (1958), for an argument that shareholders are sufficiently "protected" by the requirement that two-thirds of the class affected must assent in order to effect a charter amendment.

17 See, e.g., Federal United Corp. v. Havender, 24 Del. Ch. 318, 11 A.2d 331 (Sup. Ct. 1940); Western Foundry Co. v. Wicker, 403 Ill. 260, 85 N.E.2d 722 (1949); Franzblau v. Capital Sec. Co., 2 N.J. Super. 517, 64 A.2d 644 (Ch. 1949); 19 AM. JUR. 2D Corporations $\S 1498$ (1965).

18 Although the parties to the contract were the preferred shareholders and the corporation, the two interest groups truly concerned are the preferred shareholders and the common shareholders, whose interests were represented at the time of contracting by the corporate management.

10 See authorities cited supra note 17. See also Buxbaum, supra note 8, at 298-309.

20 Buxbaum, supra note 8 , at 298. 
of the preferred stock. Indeed, the dividend priority coupled with this accumulation feature was probably largely responsible for inducing the investor to buy preferred instead of common stock. ${ }^{21}$ Because this is the expectation of great numbers of investors in preferred stock, it is the proper construction of the preferred "contract." 22

Statutory provisions authorizing the removal of arrears should realistically be viewed as being outside the contemplation of the contracting parties. Although not within the technical doctrine of the parol evidence rule the provisions should be treated according to its principle: such statutes should not be treated as part of the contract because they are not included or referred to in the formal writing intended by the parties to be the exclusive and complete expression of their agreement. A court could achieve this result without ignoring the legislature by construing statutes authorizing recapitalizations to include an implied requirement of fairness. ${ }^{23} \mathrm{~A}$ court could hold that it is unreasonable to attribute to the legislature an intention to redistribute property rights from preferred to common shareholders contrary to their actual contract expectations, as opposed to those presumed "in law." Since the state's only legitimate interest in permitting corporations to eliminate arrears is to facilitate the raising of fresh equity capital where the presence of accruals hinders that corporate function, the statute should be construed to permit the raising of equity capital via arrearage elimination but to require that preferred shareholders be fully compensated for the rights they are forced to sacrifice in the face of the overriding public policy favoring the raising of capital.

Other less persuasive yet related arguments have also been advanced as a basis for protecting preferred shareholders from the unfair elimination of arrears. One is based on the proposition that whatever result might

21 See Becht, Alterations of Accrued Dividends: II, 49 Mich. L. REv. 565, 582 (1951).

22 Professor Latty has put the matter succinctly. To permit arrearage elimination without full compensation of preferred investors would make the common stock "a depression one-way street." Latty, supra note 10, at 39. The contract limits the preferred in good times to its contractual return of, e.g., $5 \%$ while the common is to reap the benefits of prosperity by virtue of its residual position. Yet the elimination of arrears would effectively strip the preferred of its contractual protection against bad times, the right to accumulate unearned dividends, which was bargained for at the price of a limited return in good times, and would preserve the common's position without making it bear its contractedfor risks. See also Note, supra note 9, at 1342.

23 "A judge who understands the realities of the situation need have no hesitation in treating recapitalization plans as in fact what the SEC has called them, 'management plans,' and not arms'-length bargains between independent groups of common and preferred shareholders. So treating them, he should have no difficulty in holding that it is within the power of an equity court, even in the absence of specific legisiation, to subject them to the same sort of objective test of fairness to which reorganization plans are now subjected." Dodd, supra note 16 , at 806 . 
be suggested by the technical legal doctrine that a relevant statute is part of all contracts made after its promulgation, the innocent investing public which buys securities in ignorance of the actual legal rights they have purchased should be protected from exploitation. ${ }^{24}$ In the words of Jerome Frank, this should be done "so as to protect the average security holder who is otherwise helpless. Courts of equity have a tradition of aiding the helpless, such as infants, idiots and drunkards. The average security holder in a corporate reorganization is of like kind."25 Another sentiment favoring protection is the deep-seated legal aversion to unjust enrichment. In this case, it is an aversion to the self-dealing of the common shareholders at the expense of the preferred. ${ }^{26}$ But whatever the reasons, articulated or not, the nearly unanimous view of the commentators is that the "power" of corporations to eliminate arrears should be circumscribed by some concept of a "fair equivalent" in compensating the preferred for the rights they have given up. ${ }^{2 \pi}$

\section{Choosing the Standard}

Two determinations of value are central to any discussion of whether a given plan is "fair": the valuation of the enterprise, and the valuation of the claims of the respective investor groups to shares in the enterprise. Regardless of the standard of fairness selected as most appropriate, the method of valuing the enterprise should be that used by the SEC in both chapter $\mathrm{X}$ reorganizations and in Public Utility Holding Com-

24 Professor Latty quotes a leading New York financier as saying, respecting the elimination of preferred arrears in recapitalizations: "It is my considered opinion that a large part of the argument used with preferred stockholders, in adjusting away their arrears of dividends, is solely and simply hocus-pocus. The management, backed by the common stockholders, merely exploits the financial innocence of the preferred holders." Latty, supra note 10 , at 13 . See note 76 infra.

25 Frank, Some Realistic Reflections on Some Aspects of Corporate Reorganization, 19 VA. L. REv. 541, 569 (1933). Interestingly, the Supreme Court has construed chapter XI of the Bankruptcy Act so as to provide for almost paternalistic judicial protection of public investors, as distinguished from trade creditors. In determining whether a chapter XI composition would be "in the best interests of creditors" or whether the corporation must proceed under chapter $X$ with its many safeguards including the rule of "absolute priority," the Court has held that "as a general rule" the protections of chapter X must be availed of where the rights of public investors are involved. SEC v. American Trailer Rentals Co., 379 U.S. 594, 613 (1965).

26 Cf. Barrett v. Denver Tramway Corp., 53 F. Supp. 198, 202 (D. Del. 1944) (Leahy, J.): "I believe it inequitable to allow the lower class to benefit to the detriment of the higher, in view of the traditional contract between preferred and common stockholders." See also Dodd, supra note 16 , at 817 .

27 Appraisal statutes provide for the compensation of dissenters in certain recapitalizations, notably those effected by means of a merger or sale of assets. A few jurisdictions, including New York, even provide for appraisal in the event of a charter amendment. Sce note 93 infra. But the appraisal remedy never protects shareholders who have assented to the recapitalization. 
pany Act simplifications. The expected annual earnings are capitalized at a rate which adequately reflects the risk of attaining those earnings, considering such factors as the type of industry, the firm's position in the industry, and general economic conditions..$^{28}$ On the other hand, the valuation of the respective claims of investor groups will vary with the standard of fairness chosen.

One possible standard of fairness, the relative priority or compromise approach, is wholly unsatisfactory and requires little discussion. ${ }^{29}$ Judged by this standard, a plan would be deemed fair if each class gave up some rights, the preferred getting "something" from the common in return for giving up its arrears. ${ }^{30}$ However, there is no justification for such an approach. It surely does not provide the clear standard sought; much time and expense would be lost in building up a body of case law regarding how much compensation is "enough." More important, if the preferred contract does indeed raise a reasonable expectation that the cumulative feature is an essential part of the investment, the elimination of accruals should entitle the preferred shareholder to the full value of his arrears, and no less. ${ }^{31}$ In other words, the principle of "absolute priority" should apply to the preferred's claim in the enterprise. $^{32}$

28 See, e.g., Group of Institutional Investors v. Chicago, M., St. P. \& P.R.R., 318 U.S. 523, $540-41$ (1943) (section 77 railroad reorganization); Consolidated Rock Prods. Co. v. Du Bois, 312 U.S. 510 (1941) (chapter X reorganization); Eastern Gas \& Fuel Associates, 30 S.E.C. 834 (1950) (Public Utility Holding Company Act simplification). See also 1 Bonbright, Valuation of Property ch. XII (1937); Bosland, Valuation Theories and Decisions of the Securities and Exchange Commission (1964); compare Gardner, The SEC and Valuation Under Chapter X, 91 U. PA. L. REv. 440, 460-65 (1943).

29 See Latty, supra note 10 , at 37-39.

30 See Bonbright \& Bergerman, Two Rival Theories of Priority Rights of Security Holders in a Corporate Reorganization, 28 CoLum. L. REv. 127 (1928), advocating "the theory of relative priority as distinct from the theory of absolute priority, . . . [or] 'priority of income position' as distinct from the orthodox theory of priority of principal ...."Id. at 130 .

31 Cf. Page v. Whittenton Mfg. Co., 211 Mass. 424, 428, 97 N.E. 1006, 1007-08 (1912): "[T] he common stock, which under the contract assumed the burden, must be first resorted to even to the point of extinction before the preferred stock can be compelled to contribute."

32 This principle requires that once the value of the preferred's claim has been established, the preferred will receive cash or securities which, if present expert predictions as to earnings and market valuations are realized, will equal the full value of its claim. The common is only entitled to securities the value of which is the difference between the value of the corporation and the value of the securities already allotted to senior investors. As Professor Latty has pointed out in justifying the application of the principle, if absolute priority is necessary in chapter $X$ reorganizations to effectuate contract rights, it is even more necessary in recapitalizations, where the institutional and statutory safeguards of chapter $X$ are not present. See Latty, supra note 10 , at 40. The safeguards for protecting investors in chapter $\mathrm{X}$ proceedings include: the appointment by the court of a disinterested trustee to study the debtor's finances, to report his 


\section{A. Liquidation Value-Measuring Rights Which Mature by Reason of Insolvency}

Another of the several standards of fairness which has been suggested is that of chapter X of the Bankruptcy Act. ${ }^{33}$ That statute has been construed to provide that in bankruptcy reorganizations, effected when an insolvent corporation would be worth more if reorganized and continued in operation than if liquidated, the preferred shareholders' claim to the securities of the reorganized enterprise equals their claim in liquidation, or their liquidation preference plus arrears. ${ }^{34}$ An attractive characteristic of this standard is its ease of application. No party could dispute the value of the preferred's claim: the preferred contract stipulates the liquidation preference, and unpaid arrears are easily tabulated. Furthermore, the experience of nearly thirty years with this standard in the federal courts has demonstrated that it is not impossible of judicial application, at least when sufficient facts are presented to the court. The chapter $\mathrm{X}$ formula surely satisfies the desire for a "clear standard."

Still, although desirable, clarity is not enough; this formula should be rejected because it is inappropriate in the recapitalization of a solvent corporation. ${ }^{35}$ It is used in bankruptcy reorganizations because it most nearly effectuates the contractual expectations of the parties who, by agreeing to liquidation preferences, have provided for certain rights vis-à-vis one another in the event of liquidation. Since a bankruptcy reorganization is a substitute for, and is brought about by the same operative conditions as, the liquidation of bankruptcy, it is reasonable to conclude that the parties intended the liquidation values they provided to govern in a bankruptcy reorganization. This is not so in a recapitalization. The corporation is not bankrupt, but is solvent. There is to be no dissolution; rather, the corporation is to continue operating just as before with the same investors participating. Recapitalization is not at all a substitute for liquidation, and usually occurs in circumstances far removed from those which bring on a chapter $\mathrm{X}$ reorganiza-

findings to all security holders, to ask them to submit reorganization plans, and to recommend a plan of his own to the court; and, the participation of the SEG in the proceedings and its evaluation of the various plans under consideration. Such participation by the SEC is mandatory where the bankrupt's liabilities exceed $\$ 3,000,000$, and is within the court's discretion in other cases. 52 Stat. 888, 890, 891 (1938), II U.S.C. §§ 556, 567, 57173 (1964). See SEC v. United States Realty \& Improvement Co., 310 U.S. 434 (1940).

33 See Note, The Doctrine of Strict Priority in Corporate Recapitalization, 54 YALE L.J. 840 (1945).

34 Consolidated Rock Prods. Corp. v. Du Bois, 312 U.S. 510 (1941); Case v. Los Angeles Lumber Prods. Co., 308 U.S. 106 (1939); Taylor v. Standard Gas \& Elec. Co., 306 U.S. 307 (1939).

35 See, e.g., Latty, supra note 10, at 26-27. 
tion. ${ }^{36}$ Because the parties did not intend, when providing in their contract for liquidation preferences, that this provision should govern the relative rights of preferred and common shareholders while the corporation remained a solvent and going concern, ${ }^{37}$ a standard of fairness which protects the value in liquidation of senior investments is inappropriate to a recapitalization.

If the chapter $\mathrm{X}$ approach is rejected, the standard for railroad reorganizations under section 77 of the Bankruptcy Act must surely meet the same fate. Besides being inappropriate for the same reasons as chapter $\mathrm{X},{ }^{38}$ it is not even clearly defined and easy to apply. The Supreme Court has held that the ICG possesses the greatest possible discretion in determining whether a section 77 plan is fair. So great is this discretion that the Commission need not even specify the reasons supporting its determination. In a leading case, the Milwaukee Road reorganization, ${ }^{30}$ the court of appeals reversed an order approving the plan "on the ground that the Commission did not make the findings required by Consolidated Rock . . . ." 40 which required the SEG, in chapter X proceedings, to value the enterprise and the claims of security holders and to state the bases for these determinations. ${ }^{41}$ The Supreme Court reversed the appeals court decision and held that the ICC need do no more than state its conclusions, for example, "that the stock had no value." 42

Furthermore, the Commission apparently has seen fit to take advantage of this broad immunity from the necessity of applying clear-cut standards by deciding cases inconsistently and by applying economically unjustifiable measures of value. ${ }^{43}$ According to one student of the subject who was a leading member of the reorganization bar, in those

36 See generally Dodd, supra note 16 , at 782-84. Unlike the situation where a company is insolvent, in a recapitalization "no one has the right to force the liquidation of the enterprise." Federal Water Serv. Corp., 8 S.E.C. 893, 909 (1941).

37 Cf. SEC v. Central-Illinois Sec. Corp., 338 U.S. 96 (1949); Otis \& Co. v. SEC, 323 U.S. 624 (1945).

38 The ICC uses the same liquidation value standard in assessing preferred shareholders' claims as does the SEC under chapter $X$. The value of the claim is the sum of the liquidation preference and the accumulated unpaid arrears. Missouri Pac. R.R. Reorganization, 290 I.C.C. 477, 598-95 (1954).

30 Group of Institutional Investors v. Chicago, M., St. P. \& P.R.R., 318 U.S. 523 (1943). $40 \mathrm{Id}$. at 529.

41 Consolidated Rock Prods. Corp. v. Du Bois, 312 U.S. 510 (1941).

42318 U.S. at 539. "Nor was it necessary for the Commission to make a precise finding as to the value of the road ....," ibid., or even attempt to value precisely the rights given up or those to be received in return, id. at 564-66.

43 See, e.g., Swaine, $A$ Decade of Railroad Reorganization Under Section 77 of the Federal Bankruptcy Act, 56 HARv. L. REv. 1193 (1943). For a detailed description of the ICC's administration of section 77, see Wren, The Valuation of a Railroad in Reorganization, 58 CoLUM. L. REv. 316, 323-65 (1958). 
rare cases in which the ICC has chosen to make definite estimates of expected earnings, the widely differing capitalization rates which it has applied to firms' expected earnings are not explicable in terms of any consistent or rational standard. ${ }^{44}$ Besides this unexplained inconsistency, the Commission has been guilty of approving the issuance of grossly watered stock and permitting the participation of junior security holders who have no legitimate equity in the insolvent enterprise. ${ }^{45}$ For these reasons - the inappropriateness of using a bankruptcy or liquidation value standard in the recapitalization of a going concern and the lack of clarity of the section 77 "standard" as administered-it, too, must be rejected.

A standard of fairness which remains to be discussed is Professor Latty's "funding theory." 46 It has received surprisingly little of the discussion it merits, perhaps because it is based on Federal Water Service, ${ }^{47}$ an SEC decision under the Public Utility Holding Company Act which came so early in the Commission's experience with that act that it has since been substantially refined by cases which take a different tack from that perceived by Professor Latty. He saw, as the key to that decision, "the 'funding formula': To the current dividend requirements of the preferred add the figure obtained by multiplying the aggregate arrearages by the preferred's dividend rate; ascertain what ratio this bears to anticipated net income." The quotient of the formula is "the extent to which the preferred now owns the enterprise ... ."48 This approach treats preferred arrears "as an added investment of the preferred in the company." 40 The author suggests that the problem of valuing the enterprise would be avoided simply by giving the old preferred new preferred shares in the face amount of the old stock plus accruals, bearing the same interest rate as

44 Swaine, supra note 43 , at 1200-01.

45 In the years 1940-1943, the Commission approved plans in which earnings were capitalized at rates ranging between $2.9 \%$ and $5 \% . I d$. at 1200 . Since the yield for Moody's average railroad bonds for those years ranged between a low of $3.54 \%$ and a high of $4.68 \%$, and since the bonds should be capitalized at a lower rate than the railroad's entire expected revenue because of the substantially lesser risk that sufficient money to pay the bonds will not be earned, it is clear that the Commission was grossly and unreasonably over-optimistic in estimating the risk of attaining expected earnings, with the result that the corporation was over-valued and watered securities were issued to junior security holders who had no right to participate in the reorganized enterprise at all. 1944 MOODY, Bond SURveY 514; 1943 MOODY, BOND SURVEY 590, 568; 1941 MOOdY, BOND SURVEY 792.

46 See Latty, Fairness-The Focal Point in Preferred Stock Arrearage Elimination, 29 VA. L. REv. 1 passim (1942).

478 S.E.C. 893 (1941); 10 S.E.C. 200 (1941). The case involved a holding company simplification and the question of fairness to security holders under $\S \S$ and 11 of the act.

" 48 Latty, supra note 46 , at 29-30.

$49 I d$, at 31 . 
the old contract but on the full new par. ${ }^{50} \mathrm{~A} \$ 100,6 \%$ share with $\$ 50$ of arrears would, under this approach, be treated as a $\$ 150$ investment; instead of a right to $\$ 6$ annually in dividends plus the paying off of the arrears, the shareholder would have a right to $\$ 9$ in annual dividends perpetually with no payment of arrears. Professor Latty does not attempt to justify this treatment of arrears as an additional equity investment, but merely states that it describes fairly accurately what the SEC must have done in Federal Water Service. The clear implication, however, is that this procedure meets with the approval of the author.

At first glance, there seems to be much to commend the "funding theory." It appears disarmingly simple to apply. And it is not unappealing to view accruals as a form of reinvestment in the corporation. ${ }^{51} \mathrm{It}$ is something of a compromise between acknowledging the preferred's claim to be paid the full amount of its arrears in cash before the common may participate at all and yielding to the common's contention that the preferred should share the burden of past business failures and that both classes should participate immediately in the current prosperity. ${ }^{52}$

However, its strength is also its weakness: it is a compromise. If

$50 I d$, at 36 .

51 See Blum, The Interstate Commerce Commission as Lawmaker: The Development of Standards for Modification of Railroad Securities, 27 U. CHI. L. REv. 603, 639 (1960): "The premise is that the arrearage is an involuntary investment in the firm, forced upon the preferred shareholders by the inability of the management, representing the common shareholders, to earn sufficient income to keep current on payment of preferred dividends." This kind of "forced investment" was not unforeseeable by the preferred investor when he purchased his stock; it is probably the one risk he must have foreseen. Somewhat similarly, converting the arrears into an infinitely long term "forced investment" might be viewed as merely a perpetual extension of the status of the unearned accrual as an investment.

However, although the investor realized that his accruals might take on the nature of a "forced investment" if unearned, he did not expect this to be a perpetual investment. He reasonably expected it to be liquidated as the corporation amassed sufficient earnings to do so.

52 That this approach is indeed a compromise is demonstrated by comparing its results with those of the investment value approach espoused in this comment and discussed in the text accompanying notes $56-75$ infra. In the hypothetical case used in that discussion to illustrate the application of the investment value theory, the preferred shareholders were shown to have a right to nearly $75 \%$ of the new common stock to be issued. (The value of the old preferred contract was \$872,566; the total value of the company's equity was $\$ 1,176,405$.) But under the "funding" approach, the preferred would be entitled only to $60 \%$ of the new common stock:

Formula: $\frac{\text { annual preferred dividend }+ \text { (arrears } x \text { dividend rate) }}{\text { corporation's anticipated annual income attributable to equity }}=$ percentage of the firm owned by the preferred

$$
\frac{50,000+10,000}{100,000}=60 \%
$$


the reason for protecting the preferred with a standard of fairness or full compensation is the fulfillment of contractual expectations, the contract should constitute the guideline in defining that standard. Any less is unfair to the preferred; any more is unfair to the common. ${ }^{53}$ And it is most unlikely that the preferred contract so much as suggested that accruals be treated as an additional, perpetual investment in the corporation.

Furthermore, although it is easy to apply the funding formula where the corporation plans to have only one class of stock after the recapitalization-the percentage of the enterprise owned by the preferred, represented by the quotient in the formula, is easily translated into the same percentage of the single class of equity securities-it is quite difficult if there is to be more than one class of securities. For example, if according to the Latty formula the preferred "owned" $60 \%$ of the enterprise, how would this figure be translated into its proper share of the new securities which consist of 20,000 shares of $\$ 100$ par $4 \%$ prior preferred, 10,000 shares of $\$ 100$ par $5 \%$ preferred and 40,000 shares of no-par common? In such a situation, a valuation of the corporation and of each of the classes of securities could not be avoided; yet it was precisely the avoidance of these difficult problems of valuation that was to have been such a favorable feature of the funding theory. The Latty approach does avoid one value computation, the valuation of the old preferred contract. ${ }^{54}$ However, because this is the simplest of the value computations and because there are so many guides to evaluating securities, such as Moody's tables, it is doubtful whether the funding formula's slightly simpler computation justifies choosing it over the investment value approach in light of the sacrifice in terms of legitimate contract expectations which the funding theory would entail. ${ }^{55}$

\section{B. Investment Value-Measuring Rights in a Going Concern}

Of the statutory standards of fairness which might provide a model for recapitalizations, the closest analogue is that of section 11 of the

53 Although the preferred is entitled to full compensation, it should not be overcompensated.

54 The "value" of the preferred is simply a given percentage, e.g., $75 \%$, of the value of the enterprise. The computation of the latter figure is unavoidable if more than one class of securities is to be issued.

55 The funding theory is further evidence that the proper standard is that applied under the PUHC Act, discussed below, and not one based on liquidation values such as that of chapter $\mathrm{X}$. Professor Latty recognized that the liquidation value concept was inappropriate where rights in a going concern were involved, Latty, supra note 46, at 26-27, and for this reason chose as his model what was at that time the best example of the valuation of rights in a going concern, the SEC's handling of the PUHC Act mandate in the Federal Water Service decision. 
Public Utility Holding Company Act. ${ }^{56}$ The factual situations to which the act applies are quite similar to those in recapitalizations, and the theoretical justification for the standard applies equally well to recapitalizations.

One of the act's central purposes was to "simplify" the uneconomical and confusing multi-level utility holding company systems by eliminating certain nonoperating companies from the corporate structure. The statutory requirement that the reorganization plan be "fair and equitable to the persons affected by such plan" has been construed by the Supreme Court to require a rule of absolute priority. ${ }^{57}$ Thus, the preferred must receive the "equitable equivalent" of their contract rights-cash or securities which are expected to equal the value of those rights-before the common can receive anything. ${ }^{58}$

Although the Court settied upon absolute priority without trepidation, a more difficult problem was the choice of the proper yardstick for valuing the preferred rights given up. In Otis \& Co. v. SEC, ${ }^{50}$ the Court held that liquidation value, the standard of chapter $\mathrm{X}$, was inapplicable because a PUHC Act simplification "results in a type of liquidation which is entirely distinct from the liquidation of the corporation, whether voluntary or involuntary,' envisaged by the charter provisions of Power [the corporation] for preferences to the senior stock." 60 Liquidation values in preferred contracts contemplate the liquidation of an insolvent firm, and are inapplicable where the corporation is "unquestionably solvent with large equity values in its stock." 61 Since the recapitalizing corporation, like the corporation in a section 11 simplification, is a going concern, the contractual provision regarding liquidation is equally inappropriate as a measure of the preferred's value in a recapitalization.

Under the PUHC Act, the proper yardstick for valuing the preferred's share in a going concern was held to be "investment value."62

56 49 Stat. $803,820-23$ (1935), 15 U.S.C. $\$ 79 k$ (1964).

57 Public Utility Holding Company Act, $\S 11$ (d)-(e), 49 Stat. $821-22$ (1935), I5 U.S.C. $\$ \S 79 \mathrm{k}(\mathrm{d})$-(e) (1964), construed in Otis \& Co. v. SEC, 323 U.S. 624 (1945).

68 Respecting the ways in which claims of senior security holders may be satisfied once their magnitude has been determined, see Blum, Full Priority and Full Compensation in Corporate Reorganizations: A Reappraisal, 25 U. CHI. L. REv. 417, 429-44 (1958).

59323 U.S. 624 (1945).

60 Id. at 631. See also SEC v. Central-Illinois Sec. Corp., 338 U.S. 96 (1949).

61328 U.S. at 629.

62 Id. at 631. See also SEC v. Central-Illinois Sec. Corp., 338 U.S. 96, 129 (1949). Professor Dodd has implied that this standard might be applied to recapitalizations, Dodd, Preferred Shareholders Rights-The Engineers Public Service Company Case, 63 HaRv. L. REv. 298, 307-08 (1949). But see Brudney, The Investment-Value Doctrine and Corporate Readjustments, 72 HARV. L. REv. 645 (1959). 
This approach attempts to determine "the investment value the securities would have if it were not for the liquidation required by the Act"63 by estimating the value which a normal market would place on a similar investment contract in a similar enterprise. ${ }^{64}$ Consider, for example, a strong corporation which expects to have $\$ 100,000$ in earnings available annually for its shareholders and which has 10,000 shares of common and 10,000 shares of $5 \%, \$ 100$-par preferred each with $\$ 20$ of arrears. The investment value of the preferred shares would be the sum of the value of the contract without arrears and the value of the arrears, determined as follows:

(1) The value of the contract without arrears is derived from the preferred dividend requirement of $\$ 50,000$ per year. The value of this right is the present value of $\$ 50,000$ per year in perpetuity, capitalized at a rate which properly reflects the risk of not earning the dividend. Because the corporation is strong and the risk is small, a proper capitalization rate might be $7 \%{ }^{65}$ The value of the contractual right to dividends is thus $\$ 714,073 .{ }^{66}$

(2) The second component of the preferred shares' investment value is the value of the arrears. If the company earns $\$ 100,000$ annually and pays $\$ 50,000$ in preferred dividends, $\$ 50,000$ will be available for payments on the arrears. Assuming depreciation charges sufficient to maintain the plant at a level necessary to earn $\$ 100,000$ and assuming a willing board of directors, if the entire sum is devoted to that purpose $^{67}$ the arrears will be paid off in four years $(\$ 20$ on each of

63 SEC v. Central-Illinois Sec. Corp., 338 U.S. 96, 140 (1949).

64 Id. at 144-46. See generally Brudney, The Investment-Value Doctrine and Corporate Readjustments, 72 HARV. L. REv. 645, 648-64 (1959).

65 This is assumed here to be the rate of return which a "normal" market would demand before committing funds to an undertaking of similar risk.

66 Gushee, Financial Compound Interest and Annuity Tables 709 (3d ed. 1961). The value of other aspects of the contract, such as sinking fund requirements and restrictions on dividend payments and the incurring of prior debt, may be accounted for in the selection of the proper capitalization rate in that they affect the risk of not paying the preferred dividend.

67 It is not necessary to assume, as the SEC does in PUHC Act cases, that the corporation would devote all available earnings to paying off arrears. In fact, this is a dubious assumption to the extent that it attempts to reflect actual business practice. It is common for a corporation going through a recapitalization to have had earnings available for dividends which were not paid out to preferred shareholders. Indeed, the promise that dividend payments will be resumed immediately on the condition that a recapitalization plan be approved is often a prime inducement to preferred shareholders to assent to a recapitalization.

A more realistic assumption for purposes of valuing preferred arrears might be that some fraction, such as one-half or one-quarter, of available earnings would be paid on arrears, the rest being retained for expansion, working capital, or simply as part of a 
10,000 shares; $\$ 200,000$ total arrearage accruals). The present value of $\$ 50,000$ per year for four years must be determined. Since the risk of not earning this sum is greater than the risk of not earning the first $\$ 50,000$ of the corporation's expected annual income, it should be capitalized at, perhaps, $10 \%$. Thus, the present value of the arrears is $\$ 158,493,{ }^{68}$ and the total value of the preferred rights is $\$ 872,566$.

The preferred should be given either cash or securities of this value. If the new capital structure is to consist of one class of securities such as common stock, the preferred should be given a percentage of that stock equal to the ratio of the preferred's investment value to the value of the entire equity. ${ }^{69}$ The value of the entire equity is determined by capitalizing the expected annual earnings available for the equity interest, $\$ 100,000$, in perpetuity at the appropriate rate considering the risk of not achieving those earnings (e.g., 8-1/2\%). On this basis, the total equity is worth $\$ 1,176,405^{70}$ and the preferred would be entitled to $74 \%{ }^{71}$ of the new single class of stock to be issued. If more than one class of securities is to be issued, the preferred should be given the most senior package of shares which will, if present expert expectations are realized, have a market value equal to the preferred's present investment value. ${ }^{72}$ The expected market value of the new shares is estimated in the same manner in which the investment value of the old shares was determined. The earnings attributable to the new shares are capitalized at a rate which the market would probably require of a security of similar quality in a similarly-situated company.

In this way, "the equitable equivalent of the securities' investment value on a going concern basis" 73 is most accurately determined, ${ }^{74}$ and it is on the basis of this determination that the preferred should be made whole in the event of a recapitalization. The twofold reason given for

conservative financial policy. Under this approach, the present value of the arrears in the above hypothetical would not be $\$ 158,493$ but would be $\$ 133,373$. $(\$ 50,000$ annually is available for arrears; assuming that one-half would be used for that purpose, $\$ 25,000$ is applied against arrears; the present value of $\$ 25,000$ each year for eight years capitalized at ten per cent is $\$ 133,373)$. GusheE, supra note 66 , at 731 .

B8 Ibid.

69 The principle of "absolute priority" would actually require giving the preferred a larger share to compensate for the loss of the priority of its claim to dividends.

70 GusHeE, supra note 66 , at 721 .

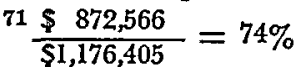

$72 \mathrm{~A}$ check can be made of this allocation. The expected market value of the securities given the preferred and those given the old common shareholders should equal the computed total value of the equity interest.

73 SEC v. Central-Illinois Sec. Corp., 338 U.S. 96, 129 (1949).

74 See Eastern Gas \& Fuel Associates, 30 S.E.C. 834 (1950). 
adopting this standard in section 11 simplifications applies as well to recapitalizations. On the one hand, it is more in keeping with the intent of the preferred contract, ${ }^{75}$ which contemplates the preferred investor's receiving stipulated cumulative dividends as long as the company continues in business, the only risk being whether the corporation will earn and be in a position to pay the dividend. On the other hand, while the elimination of contractual rights may be sanctioned as furthering the legitimate governmental function of facilitating the raising of new capital, $^{\text {t6 }}$ the intention to achieve this goal by the dubious means of shifting property rights from one class of investors to another should not be attributed to a legislature. ${ }^{77}$

That the "investment value" concept of the PUHC Act is the proper measure of what preferred investors in a recapitalization are called upon to relinquish, and is therefore also the proper measure of what they should receive in order to be compensated fully, is further demonstrated by the development of doctrine under section 20(b) of the Interstate Commerce Act. ${ }^{78}$ That section deals with the "modification of railroad financial structures"79 and also furnishes a close analogy to recapitalizations in that it provides for the changing of investors' rights in a solvent corporation. The statute was passed as a reaction to the long, expensive procedures of section 77 bankruptcy reorganizations for railroads. Its central purpose was to permit the roads, under ICG supervision, to extricate themselves from oppressive burdens of accumulated debt and preferred dividends when these threatened to continue accumulating and force the corporation into bankruptcy. ${ }^{80}$ However, the statute's

75 Cf. SEC v. Central-Illinois Sec. Corp., 338 U.S. 96, 129-32 (1949).

76 But see Dodd, Fair and Equitable Recapitalizations, 55 HARv. L. REv. 780, 783-84 (1942), where it is pointed out that very few if any recapitalization plans are followed by common stock financing, giving rise to the inference that the real purpose of management in attempting recapitalizations is to enrich the common at the expense of the preferred.

77 Cf. SEC v. Central-Illinois Sec. Corp., 338 U.S. 96, 134-35 (1949): "Congress, in its efforts to achieve a popular economic goal, wished to avoid shifting investment values from one class of securities to another ... [and] "intended to exercise its power with the least possible harm to citizens.' "

7871 Stat. 369 (1957), 49 U.S.C. $\$ 20(\mathrm{~b})$ (1964).

79 Ibid. See generally Hand \& Cummings, Funding Arrearages Under Section $20 b$ of the Interstate Commerce Act, 65 HARv. L. REv. 398 (1952).

80 Cf. Wood v. United States, 132 F. Supp. 586 (S.D.N.Y. 1955). The main purpose of the act, as stated by Congress, is laudable: to "avoid the deterioration of service and the interruption of employment which inevitably attend the threat of financial difficulties and which follow upon financial collapse ... and to enable said common carriers, insofar as possible, to avoid prospective financial difficulties, inability to meet debts as they mature, and insolvency." 49 U.S.C. § 20(b) (1964), p. 375, quoting Act of April 8, 1948, § 1, 
language is not limited to those situations, and a probable inability to meet future debts is not a necessary condition to its use.

At least one road has attempted to use this statute as a device to eliminate preferred arrears and immediately resume dividends on common stock. In the Maine Central modification, ${ }^{81}$ the corporation sought to eliminate the $\$ 85$ per share arrearage on the $5 \%$ preferred by exchanging the old stock for new $\$ 185$ par $4 \%$ preferred. ${ }^{82}$ The Commission refused to approve the plan for several important reasons: first, the railroad had omitted to produce sufficient information for the ICC to estimate future earnings properly; ${ }^{83}$ second, the plan was not "in the best interest of the preferred stockholders" because "the holders of the preferred stock are thus asked to yield their preferred position as to participation in the applicant's earnings available for dividends, while the holders of the common stock are asked to make no sacrifice whatever but are placed in a much more favorable position as to participation in such earnings"; 84 and third, the plan was not in furtherance of the policy of section 20 (b) because, since the company was doing well, it was not necessary to avoid financial difficulties and was not part of a program to improve its credit and attract additional capital. ${ }^{85}$

Of more interest than this holding, however, was the dictum of the Commission as to the standard which the ICC applies in determining whether an elimination of arrears is "in the best interests" of the

cited to text. But the purpose regarding preferred rights is more dubious: "to enhance the marketability of railroad securities impaired by large and continuing accumulations of interest on income bonds and dividends on preferred stock . . . ." Ibid. There is no good reason to reallocate property rights from senior to junior investors. It would seem beyond the proper province of Congress to seek "to enhance the marketability" of common stock at the expense of the contractually bargained-for rights of the preferred. Such a policy is subject to the criticisms discussed in the introduction to this comment. The only proper role for the elimination of preferred arrears is to expedite the raising of additional equity capital. Even here, the preferred should be compensated as fully as possible, with the common stockholders bearing the brunt of any necessary financial sacrifice.

For a thorough discussion of the background and purposes of $\S 20(\mathrm{~b})$, see Blum, The Interstate Commerce Commission as Lawmaker: The Development of Standards for Modification of Railroad Securities, 27 U. CHI. L. REv. 603, 604-10 (1960).

81 Maine Cent. R.R. Sec. Modification, 275 I.C.C. 261 (1950). The Commission said of the plan: "The primary effect of these proposals would be to eliminate the accruals of $\$ 2,550,000$ of unpaid dividends on the preferred stock, and to place the security on a current dividend basis. It would further result in ... permitting the payment of dividends on the common stock." Id. at 266. See also Wood v. United States, 132 F. Supp. 586 (S.D.N.Y. 1955), reversing the Commission's decision in Western Md. Ry., 290 I.C.C. 445 (1954), to approve a plan similar to that proffered in Maine Central.

82275 I.C.C. at 264-65.

$83 \mathrm{Id}$. at 282.

84 Id. at 283 .

$85 \mathrm{Id}$. at $284-85$. 
preferred. ${ }^{86}$ The Commission said that the same "principles governing the modification of stock-holders' rights" under the PUHC Act apply to section $20(\mathrm{~b}){ }^{87}$ The Commission cited Otis and Central-Illinois as controlling authority ${ }^{88}$ and went through the mechanics of comparing the present value of the rights to money payments based on foreseeable earnings of the existing preferred contract with the present value of the rights offered in the plan. ${ }^{89}$ In Boston of Maine R.R. Sec. Modification, ${ }^{90}$ decided two months later, the ICC approved a plan eliminating arrears and reaffirmed that the proper standard for determining what the preferred stockholders should be given in return for this sacrifice was the same as that applied by the SEC in PUHC Act simplifications, at least where, as in Maine Central and Boston of Maine, the corporations involved were financially successful. It may be, as has been suggested by at least one commentator, that the Commission is not consistent in its administration of the Railroad Modification Act, ${ }^{91}$ and that even when it purports to apply the investment value standard it does not do so properly. ${ }^{92}$ Still, whether or not the ICC fully comprehends or utilizes the mechanics of the investment value standard does not detract from the importance of its having been persuaded by the logic which compels

86 The statute requires the change to "be in the best interests . . of each class of its stockholders, and of the holders of each class of its obligations affected by such modification or alteration ...." 71 Stat. 369 (1957), 49 U.S.G. \& 20(b)2(c) (1964).

87 This is precisely what Professor Dodd had suggested one year prior to the Maine Central decision. See Dodd, Preferred Shareholders Rights-The Engineers Public Service Company Case, 63 HaRv. L. Rev. 298, 306 (1949).

88 Maine Cent. R.R. Sec. Modification, 275 I.C.C. 261, 271 (1950). See also Hand \& Cummings, supra note 79, at 411-12, 416-17; authorities cited in Brundey, The Investment-Value Doctrine and Corporate Readjustments, 72 HARv. L. REv. 645, 646 n.4 (1959).

89 Maine Cent. R.R. Sec. Modification, 275 I.C.C. 26I, 273-74 (1950). See Comment, Allocation of Securities in Corporate Reorganizations: Claims Measurement Through Investment Value Analysis, 61 YALE L.J. 656, 676-82 (1952); Note, Protection for Shareholder Interests in Recapitalizations of Publicly Held Corporations, 58 Colum. L. REv. 1030, 1061 (1958).

90275 I.C.C. 397 (1950).

91 See generally Billyou, Railroad Reorganization Under Section $20 \mathrm{~b}$ of the Interstate Commerce Act, 39 VA. L. REv. 459, 465 (1953); Blum, The Interstate Commerce Commission as Lawmaker: The Development of Standards for Modification of Railroad Securities, 27 U. CHI. L. REv. 603 (1960). Both authors conclude that the ICC does not apply any consistent formula in 20 (b) cases and is merely "feeling its way." Billyou, supra at $48 \mathrm{I}$. If this be true, the Commission, in dealing with a statute that does "not require the ICC to make any clear distinction between various competing priority theories," $i d$. at 484 , is behaving as inconsistently as it does under a similarly permissive statute, section 77 of the Bankruptcy Act. Compare Maine Cent. R.R. Sec. Modification, 275 I.C.C. 261 (1950), with Sakis v. United States, 103 F. Supp. 292 (D.D.C. 1952). See also Comment, The Full Compensation Doctrine in Corporate Reorganizations: A Schizophrenic Standard, 63 YALE L.J. 812 (1954).

92 See Blum, supra note 91; Blum, The Investment Value Standard Under the Railroad Modification Act, 45 Nw. U.L. Rev. 357 (1950). 
the adoption of that standard in determinations of full and fair compensation for rights relinquished in a thriving company.

\section{Doctrines of Fairness in State Law and the Analogy to Appraisal Statutes}

A perusal of state recapitilization law fails to shed light on the problem of developing an appropriate standard. Nearly every state permits the elimination of arrears by one device or another without an examination into the fairness of the exchange. ${ }^{93}$ Two notable exceptions are Nebraska and California, each of which deals with this problem in its own unique way. A Nebraska statute directs the court, on the petition of a dissatisfied shareholder, to "enjoin any of the proposed amendments if the proponents of the amendment fail to show that, to a reasonable probability, they are fair, just, and equitable to all shareholders affected thereby." 94 Thus, the obstacle to shareholders' suits presented by the shareholders' lack of access to the information necessary to formulate a meaningful argument on the issues of valuation and fairness has been surmounted in Nebraska by placing the burden of proving the plan's fairness upon the corporation, which seeks to change the status quo and has access to all necessary information. It has been said that this imposes no additional financial burden on the corporation because a conscientious management would have to collect and analyze such data in coming to its own conclusions as to what plan to adopt. ${ }^{95}$ Unfortunately, no case applying the statute has been found, so there is no indication as to what standards the Nebraska courts use in deciding whether a corporation has carried its burden of demonstrating its plan's fairness.

California's statute differs from Nebraska's in that the primary authority to disapprove plans resides in the Corporations Commissioner rather than in the courts. The Commissioner may "refuse to issue a permit authorizing such exchange if in his opinion the plan is not fair, just, or equitable to all security holders affected." $96 \mathrm{He}$ has extensive powers to demand records and make a detailed study of the corpora-

93 See, e.g., Note, Protection for Shareholder Interests in Recapitalizations of Publicly Held Corporations, 58 Colum. L. REv. 1030 (1958). However, a few jurisdictions permit dissenting shareholders to have their shares appraised and purchased in the event of a charter amendment. Note, Limitations on Alteration of Shareholders' Rights by Charter Amendment, 69 HaRv. L. Rev. 538, 544 (1956). Even in those few states, however, the right is very narrowly circumscribed. Note, Appraisal Statutes-An Analysis of Modern Trends, 38 VA. L. REv. 915, 919-21 (1952).

94 NEB. REv. STAT. § 21-1162 (1954).

95 See Note, Limitations on Alteration of Shareholders' Rights by Charter Amendment, 69 HARv. L. REv. 538 (1956).

96 CAL. CORP. CODE $§ 25510$. 
tion's financial position, and if the Commissioner is dissatisfied with the evidence submitted, he may order a full investigation by his own experts at the expense of the corporation..$^{97}$ As in Nebraska, the corporation has the burden of proving the fairness of its plan. ${ }^{98}$ Unfortunately, although the Commissioner has passed on as many as 225 plans within a ten-year period, ${ }^{99}$ he has been very careful to guard closely whatever secret formula he may use as a standard in determining the fairness of plans. ${ }^{100}$ Orschel's study of the Commissioner's files ${ }^{101}$ not only does not reveal any consistent pattern of decision, but it does not even indicate that any identifiable standard was used in any one case. Thus, whatever experience these two states may have had in protecting preferred shareholders is not available to aid other states which seek to deal with this problem.

It is appropriate at this point to call attention to the appraisal remedy granted by many states to dissenting shareholders in mergers and certain related situations. An appraisal remedy is available in recapitalizations within the ambit of such statutes, such as those accomplished by merger with an inactive subsidiary. The purpose of appraisal statutes is the same as the objective of the standard of fairness suggested in this comment, that is, the full compensation of dissenting shareholders for the loss of a valuable right in the corporation. ${ }^{102}$ Appraisal statutes, too, recognize that "the stockholder is entitled to be paid for that which has been taken from him, viz., his proportionate interest in a going concern." 103

Appraisal doctrine is relevant to a discussion of fairness in recapitalizations because of the identical purposes and the similar facts with which both concepts are concerned. Furthermore, appraisal cases vividly demonstrate the ability of courts to adjudicate questions of fair value and full compensation. However, the doctrine which has evolved in appraisal cases does not support the proposition advanced here, that

97 Cal. Corp. Code $\$ \S 25506,25350-56 ; 10$ CaL. Admin. Code $\S 765$. See generally Orschel, Administrative Protection for Shareholders in Califormia Recapitalizations, 4 STAN. L. REv. 215 (1952).

98 Orschel, supra note 97 , at 222.

99 Id. at 219.

$100 \mathrm{Id}$. at 224, 235-36.

101 See Orschel, supra note 97.

10219 AM. JUR. 20 Corporations $\S 518$ (1965). There is also a difference between the ordinary appraisal situation and full compensation in a recapitalization. Whereas appraisal in a merger compensates the shareholder who elects to sell his security rather than to participate in the new corporation, the dissenter in a recapitalization may be compensated in new securities, in which event he would remain an investor in the corporation. 103 Tri-Continental Corp. v. Battye, 31 Del. Ch. 523, 526, 74 A.2d 71, 72 (Sup. Ct. 1950). 
investment value be the criterion for determining full compensation for dissenting preferred shareholders in recapitalizations.

The method for appraising the dissenter's "proportionate interest in a going concern" is quite different from the method used under the PUHC Act and suggested here for recapitalizations. Appraisal courts have expressly rejected the capitalized earnings method as the sole basis for valuing the rights given up by the dissenter, ${ }^{104}$ and use it only in conjunction with the other two bases of valuation which they generally accept, market value and asset value. ${ }^{105}$ They insist upon what can only be an arbitrary weighting of these three valuation methods ${ }^{100}$ and seem to approve appraisers' determinations on an ad hoc basis. Indeed, the courts have laid down no clear guidelines to valuation in appraisals and seem disinclined to do so. ${ }^{107}$

Although a detailed analysis and criticism of appraisal doctrine is beyond the scope of this comment, it should be noted in this regard that respected authorities have severely criticized the use of valuation methods other than investment value. Discussing valuation in appraisals, Professor Bonbright points out that: "It should hardly be necessary to point out that market value is utterly inapplicable."108 He suggests investment value as the proper standard, and points out that factors such as asset value and market value are relevant only "as indirect clues to the prospective earnings of the enterprise." 109 Professor Dewing states that "the capitalization of earnings is the only means at our disposal for determining the value of a going business." 110

104 Felder v. Anderson, Clayton \& Co., 39 Del. Ch. 76, 159 A.2d 278 (Sup. Ct. 1960), cited with approval in Levin v. Midland-Ross Corp., 194 A.2d 50, 55 (Del. Ch. 1963).

105 Felder v. Anderson, Clayton \& Co., 39 Del. Ch. 76, 159 A.2d 278 (Sup. Ct. 1960); Levin v. Midland-Ross Corp., I94 A.2d 50, 54 (Del. Ch. 1963). See Annot., 38 A.L.R.2d 442 (1954); BAKER \& CARY, CASES ON CoRPORATIONS 1481-82 (1958) and authorities cited there. Some courts even condone the consideration of such irrelevant factors as depreciated reproduction cost of assets. See, e.g., Felder, supra. In Levin, supra, the court noted that book value is generally disapproved as a measure of securities' value but accepted it as a fair approximation of "true value" under the circumstances. But see Ahlenius v. Bunn \& Humphreys, Inc., 358 Ill. 155, 192 N.E. 824 (1934), and the authorities cited there, refusing to rely on book value.

106 See Note, Appraisal Statutes-An Analysis of Modern Trends, 38 VA. L. REv. 915, 932-33 (1952).

107 See Note, supra note 106; Annot., 38 A.L.R.2d 442 (1954).

1082 Bonbright, Valuation of Property 828 (1937).

109 Id. at 836. See Gordon, The Investment, Financing \& Valuation of the CoRPORATION ch. 5 (1962). Gordon states that "A number of economists . . . maintain that a rational investor should only consider a corporation's earnings in valuing a share." Id. at 55. Essentially, he agrees with these economists, but contends that investors base their decisions on dividend payments as well.

110 I Dewing, The Financial Policy of Corporations 297 (4th ed. 1941). 
Market value cannot be accepted as an independent basis for valuation because investors are often uninformed, because they act for irrational or speculative (as opposed to long term investment) reasons, and because it is difficult to ascertain what the market price would have been absent the fact of the recapitalization itself. ${ }^{111}$ In addition, there might not be an active market in the securities of the recapitalizing company upon which to rely in a given case. Reliance on asset value is also misplaced because it is a liquidation, not a going concern, standard. The replacement or sale value of assets is irrelevant to the valuation of shares in an enterprise which is not considering liquidation or the sale of those assets. If, on the other hand, the term asset value means some measurement of what the firm will earn with those assets, it is little more than an unnecessary complication of the investment value concept. ${ }^{112}$

Appraisal doctrine presents less of an obstacle in the path of the recapitalization standard of fairness suggested in this comment when it is realized that courts do recognize, in theory, that the object of an appraisal is to determine the value of the business as a going concern. ${ }^{113}$ That they err in the method they have chosen to achieve that objective argues more persuasively for the adoption of the PUHC Act standard in appraisal cases than it does for the impropriety of that standard in recapitalizations.

\section{ConCLUSION}

When preferred arrears are eliminated in the recapitalization of a solvent company the preferred should be compensated fully for the rights they are forced to relinquish. The proper measure of the value of those rights is the "investment value" standard applied under section 11 of the Public Utility Holding Company Act because this approximates most closely the value of the preferred shares as an investment in a going concern, and this value is precisely what the investor is called upon to part with. The liquidation preference of the contract is not the proper measure of what the investor is giving up because it was intended to delineate the preferred's claim on the corporation only in the event

111 For a criticism of the New York market value rule, see Note, Corporation LawDissenting Stockholder's Right to Appraisal-Determination of Value, 28 N.Y.U.L. REv. 1021 (1953).

112 "Taken in a broader sense of 'going concern' value, including intangible factors, such as good will ... the asset approach becomes indistinguishable from the investment approach .... Discussion of earnings, past and prospective, is suggestive of the investment approach, but formulae for the capitalization of earnings are often applied with the purpose of establishing asset values, particularly intangible assets, such as good will." Annot., 38 A.L.R.2d 442, 446 (1954).

113 Sporborg v. City Specialty Stores, Inc., 35 Del. Ch. 560, 123 A.2d 121 (Sup. Ct. 1956); Tri-Continental Corp. v. Battye, 31 Del. Ch. 523, 74 A.2d 71 (Sup. Ct. 1950); Levin v. Midland-Ross Corp., 194 A.2d 50 (Del. Ch. 1963). 
of the termination of the corporation's existence. The only lesson which can be gleaned from the experience of the courts and agencies of the federal, state, and foreign governments ${ }^{114}$ which have attempted to compensate preferred shareholders in such situations is that such a scheme is neither visionary nor impractical, but rather that it can easily be made to work. ${ }^{115}$ A sense of justice and fairness demands that it be tried.

114 Apparently the British and Canadians have had no difficulty with their system whereby recapitalizations are subject to judicial supervision on the issue of fairness. See Latty, Exploration of Legislative Remedies for Prejudicial Changes in Senior Shares, 19 U. Chi. L. Rev. 759, 768-69 (1952).

115 This is clearly the leitmotif of Orschel's article on California's experience with administrative supervision of recapitalizations. See Orschel, supra note 97. 